\title{
Theorizing Research Ethics for the Study of Psychological Phenomena from Within Relational Everyday Life
}

\author{
Jaakko Hilppö ${ }^{1}$ (D) Niklas Alexander Chimirri ${ }^{2} \cdot$ Antti Rajala $^{1}$ \\ Received: 18 February 2019 /Revised: 31 May 2019 /Accepted: 5 June 2019/ \\ Published online: 13 November 2019 \\ (C) The Author(s) 2019
}

\begin{abstract}
How to investigate psychologically relevant phenomena in the most ethical ways possible is an enduring question for researchers not only in psychology but also in adjacent fields that study human subjectivity. Once acknowledging that both researchers and the people whose lives they want to study are human beings acting in a common world, also inhabited by non-human beings, the relationship between researchers and participants touches upon fundamental questions not only about what it means to do research together, but also what it means to conduct life in this world together. This implies that questions regarding what counts as ethical conduct need to be accentuated and also profoundly redrawn given the encompassing complexity of these relations. In this article, we will shortly review the theoretical foundations and associated problematics of the dominant view of the researcher-researched relationship in current psychological (and other) research ethics. We then present and discuss what we mean by a relational ethical position from within practice and for practice. We will also shortly introduce how the other contributions to this special section advance the theoretical debates on research ethics.
\end{abstract}

Keywords Relational ethics $\cdot$ Everyday life $\cdot$ Psychology $\cdot$ Ethics

The contribution between the authors (Jaakko Hilppö, Niklas Chimirri \& Antti Rajala) to this introductory section has been equal.

Jaakko Hilppö

jaakko.hilppo@helsinki.fi

Niklas Alexander Chimirri

chimirri@ruc.dk

Antti Rajala

antti.rajala@helsinki.fi

Extended author information available on the last page of the article 
"For in fact, we owe the very possibility of our having a life of our own to their [the others] responsiveness toward us" (Shotter 2005, p. 129).

"There is no alibi in being" (Bakhtin 1993).

This special section brings together a collection of articles that all focus on an enduring question for the field of psychology: how to investigate psychologically relevant phenomena in the most ethical ways possible? Since its inaugural issue in 1953, the American Psychology Association's Ethical Principles of Psychologists and Code of Conduct has reached its 9th revision in 2002 with amendments made as recently as 2017, and the British Psychological Society released a revised version of their Code of Ethics and Conduct in 2018. The Library of Congress lists more than 1200 books under the subject of "ethic" and "psychology" with the oldest ones dating to the latter half of the nineteenth century. ${ }^{1}$ More recently, a number of books, special issues and impactful articles regarding research ethics have been published regularly in various psychological journals or in neighboring fields (e.g., Baumrind 1964; Keehn 1982; Brinkmann and Kvale 2005; Etzel and Watson II 2006; Harlow and Oswald 2016; Campbell and Morris 2017). What the volume of these works speak for is that the boundaries of ethically sound research need to be continually reflected on, explored and redefined, mounding in a historically situated negotiation process that pertains to psychology just as much as to any other field of research that investigates human subjects, be it their psyche, their actions, their cultures, their knowledges, and so on. Psychological ethical problems are common to any research practice that seeks to theorize on behalf of other human beings, and arguably, on behalf of anything that constitutes human beings.

This special section puts its main focus on how the relationship between the researcher and the people whose lives are studied is conceptualized and theorized. A central premise that frames these explorations is the claim that human ways of being and becoming in the world are fundamentally relational. Well captured by Shotter (2005) in the quote above, this relationality does not only refer to the way in which independent individuals are connected and interact together (a weak relationalist perspective according to O'Doherty and Burgess 2019). More significantly, the premise of relationality captures the seemingly paradoxical condition of our being, the fact that we are each given birth and sustained by the way in which others respond to us (a strong relationalist perspective according to O'Doherty and Burgess 2019). That is, we become ourselves and are ourselves through others. This proposition underlines the fact that our way of being-in-the-world is relational from its very inception, and that each of us emerges on the basis of this fundamental condition of responsiveness.

For us, this intersubjectively plausible premise holds deep ethical implications that cannot be neglected, either in the practice of psychological research or elsewhere in everyday life. As Bakhtin above notes, when we owe our existence in the world, to the world, and the others in it, this comes with moral responsibility. There is no neutral position, no place from where we can look at the world as if detached from its events, as if not responsible for what is going on. We are then and there, present as persons and hence morally implicated through our relation to the world and others in it. Not only does such relationality highlight how our research work is made possible in the first place, by how the people whose lives we want to understand respond to us, but most importantly how the way we respond and interact with these people, and they with us, implicates us in each other's lives. From a relational stance, being human entails an

\footnotetext{
${ }^{1}$ e.g., Bain, A. (1868). Mental and Moral Science: A Compendium of Psychology and Ethics. London: Longmans, Green, and Co.
} 
ethical commitment to other people, a moral debt to do good to one another given our inextricably relational origins (see also Taylor 1991).

\section{The Conceptual Status Quo of the Researcher-Researched Relationship}

The relationship between the researcher and the researched, as it is theorized in current psychological and many other research ethics, in contrast to more relational perspectives, is to follow a set of principles safeguarding the individual test person's fundamental rights when acting as research object. These principles were developed in the middle of the twentieth century in response to severe mistreatment of human research subjects in medical experiments. While these sets of principles, like the Nuremberg Code of Ethics or the Helsinki Declaration, marked a leap forward in ensuring research participants' human rights, they have also met with strong criticism from both the humanistic and the social sciences (e.g., Dingwall 2012; Emmerich 2016). This can both be related to the increasing proliferation and acceptance of qualitative research across fields of research (e.g., Roth 2005; see also Miller et al. 2012; Unger et al. 2016), but also to new digital possibilities to scrutinize (massive) amounts of (partly sensitive) data without the knowledge of the researched person(s) in question (e.g., Markham et al. 2018).

These debates are highly relevant to psychology and adjacent fields of research that study human subjectivity. The natural-scientific paradigm ingrained in, for example, the Nuremberg Code, is ill-equipped for the study of complex psychological phenomena, and of how they play out in everyday life. Most fundamentally, the paradigm renders it impossible to address the problematic positioning of research participants as objects that can be experimented on and controlled, as it ignores the mutually constitutive relationship of researcher and researched (Strong 2005). For instance, psychological theoreticians such as Holzkamp (2013) crucially remind us that even in experimental setups, psychologists are dependent on the participants' willingness to actively read and act on the situational circumstances, in that they are implicitly asked to act as if they were "test subjects," or more precisely objects of the experimenter's inquiry. For inquiry concerned with subjectivity, Holzkamp therefore argues that even lab research would essentially need to be explored and understood from within a conceptual framework that takes its point of departure from everyday human practice. Such analyses would start from within the relationship between the researcher and the researched (see also Shotter 2005, 2013). Similarly, Martin et al. (2003) note that psychology based on the naturalscientific paradigm has paid too little theoretical attention to how the research participants themselves interact with the research, not just by complying with the researcher's requests, but crucially with how they later react to the research and its results, for example by interpreting their own lives though the research results. In short, conceptualizing and treating research participants as natural kinds (akin to inanimate physical entities) rather than psychological kinds (beings shaped by the practices and classifications of their practices, cultures and societies) neglects or even willingly undermines the agency of the participants.

Another side of the debate has focused on the proclaimed universality of ethical guidelines. According to the critics, irrespective of whether professional communities can reach an agreement on the rules of proper ethical conduct or not (e.g., establish an ethical code for psychological research), the rules themselves do not tell when or how we should abide by them (Jonsen and Toulmin 1988; cited in Brinkmann and Kvale 2005; cf. also Allen and Israel 2018). With regard to informed consent, for instance, although several ethical guidelines 
emphasize the transparent provision of adequate and sufficient information about the possible consequences of participation, the concrete assessment of whether these criteria are met are largely left up to the deliberation of the respective researcher(s) (see also O'Doherty and Burgess 2019; Lee 1999 on a similar fundamental ambivalence in the UN Convention on the Rights of the Child). As such, guidelines that are taken to be of universal validity, and are in consequence to be applied to any case irrespective of context, can, from a relational perspective, introduce rules and regulations into the researcher-researched relationship that are not necessary for ensuring mutual ethical conduct. As a result, such guidelines weaken their own impact and create an artificial, conceptually detrimental distance between the researcher and the researched (e.g., Wilson and Hodgson 2012).

Postcolonial scholars in particular have criticized the fact that universalist ethical guidelines further mystify their socioculturally contextual specificity, and implicitly reproduce ethnocentric Western ideals about what is ethical in life, by grounding its determination in an abstract process of rational deliberation not open to other forms of being, i.e., of conducting everyday life (e.g., Andreotti 2011; Toulmin and Toulmin 1992). In practice, the application of universal rule-based ethics, including the establishment of institutional review boards (IRB) as obligatory passage points before any research work can be carried out, have also raised concerns about how the ethical deliberation regarding different research projects has slipped away from the professional communities doing the actual research work (Dingwall 2012). Similarly, the highly bureaucratic process of gaining IRB approval runs the risk of alienating early career researchers from ethical deliberation (e.g., Sleeboom-Faulkner et al. 2017), a task they will unavoidably face once they come to implement their research work together with other human beings in practice. When gaining approval becomes a hindrance or an obstacle for conducting the research, instead of an opportunity to reflect on possible ethical dilemmas with senior and other fellow colleagues, the moral ground for applying the required ethical guidelines is weakened in actuality.

If we take these critiques and debates to heart, what avenues open up for psychological research? If psychology, as we think, is fundamentally about the study of human ways of being and becoming, as suggested by Valsiner et al. (2016), what then are the ethical ways in which these phenomena can be approached and investigated? For us, one necessary way forward would be to acknowledge that psychological phenomena need to be scrutinized from within everyday human practice, from within the immanent relationality of the researcher and the researched, in terms of a relational ethics. To illustrate what we mean by this, we will in the remaining pages suggest some central conceptual features of a relational ethics that is to foundationally reconfigure the researcher-researched relationship as inextricably intertwined in one another's everyday lived life.

\section{Relational Ethics}

A central tenet in relational ethics is the fundamental reframing of the context for ethical decision-making, especially with regard to situating the relationship between the researcher and the researched (e.g., Piper and Simons 2011). Whereas conventional rule-based, procedural ethics highlights the ethical decision-making of independent individuals based on their own rational deliberation, relational ethics underscores the fundamental connection between people (Austin 2007; Pollard 2015). In relational ethics, primacy is placed on the relationship between persons and on their constitutive interdependency as the ground for ethical decisionmaking. Hence, the particularity of who the people involved are, of their respective 
attentiveness to each other and their lives, shall be able to come to the fore. In this context, ethical guidelines are more rules of thumb than absolute rules, and used as part of many other contextual resources available to the persons in the decision-making situation (Brinkmann and Kvale 2008). Pollard $(2015,366)$ suggests for example that "we may choose to use our knowledge of the ethical principle of justice and our experiences with compassion to help guide ethical action." Relationality does not, however, only refer to the constitutive relation between human beings. In various traditions of thought, the mutual constitutiveness of human beings and the world more generally is theorized. This implies that we are always and already implicated in an ethical relationship with the world. Each action we take has a moral side to it, most often without us noticing, and brings about many of consequences, some unexpected. Therefore, engagement in an ethical relationship is not considered a decision but a consequence of how we are and seek to be in the world.

A second central tenet in relational ethics concerns the openness of the dialog between the researcher and the researched and of how that relationship evolves. In relational ethics, the ethicality of actions is not determined by the extent to which they follow any given ethical norms, or by how ethical dilemmas are solved on their grounds. Rather, being ethical means being attentive and responsive to the other people in the relationship (Austin 2007). To realize this, researchers are not only called to question their assumptions and possible predispositions regarding the persons whose lives they want to investigate, but also to be open to how these people come to co-define the relationship and thereby the researcher. Being ethical means, then, fundamentally being available, responsive and present to the other people in the relationship, including being ready to engage with their concerns. In this sense, the researcher's position in relational ethics could be characterized with Levinas' term of radical passivity (Hofmeyr 2009; Roth 2010), one of being fundamentally open to the other. As Austin (2007) notes, this does not, however, mean that "anything goes" in relational ethics. Rather, it highlights the need to be sensitive and inclusive in our dialogue with the people we want to study our being-in-the-world together with. Importantly, it also means that the dialogue is unfinalizing, open to what the other people bring to it, and does not seek to determine define or categorize them. This openness does not stop with the establishment of the research relationship, but continues as the relationship evolves during the research and beyond (Ellis 2007).

By highlighting the need to being open to the concerns and actions of those we research, or rather of those we do research together with, relational ethics calls the researcher to understand herself as a participant in the everyday life of the researched rather than as a spectator of their everyday life (Maffesoli 1989; Brinkmann 2012). Hence, relational ethics acknowledges the related theoretical and ethical-political challenges that, among others, have long been pointed out by both practice philosophy and feminist philosophy (Dewey 1920; Haraway 1991; Mol 2008): researchers are, after all, not only in the world, they are of the world (Barad 2007; also Ingold 2013). This then further requires the researcher to take the social worlds of the people who are part of the research, and their constitutive nature, seriously. Here relational research ethics explicitly entails a political dimension-given that social relationships are laden with power, situated in specific historical circumstances, and "weighted by social gravity" (Erickson 2006). This fundamental acknowledgement of the researcher's contribution to the lives of the researched implies conceiving of ethics beyond an exclusively protectionist agenda, beyond an avoidance of harm exerted qua the authority of the researcher. Instead, the focus must be directed toward how the researcher aims to work, together with the researched, on ameliorating the living conditions of the researched - and possibly also the living conditions of the researcher, namely working together towards a common good, or for one another's well-being. 
But what is this common good, the virtues and/or values, that psychological researchersor following Anna Stetsenko (2008, 2015): transformative activists - strive towards? And how can we work on promoting them via our research? Should we promote them at all? If we see the ultimate goal of research being the production of new knowledge for the benefit of all humanity, other beings in the world and nature, is this enough to ensure that the common good is served? Given that what is good, when and for whom, is a contested terrain, is it possible for us as researchers to avoid reinserting instrumentalist conceptualizations? Here, working with relational ethics raises critical questions in particular about interventionist psychological research, in which the outcome of a successful intervention is by and large predefined by the researchers, and in which the research participants' deviance from the scripted course of the intervention design are usually considered unproductive breaches of fidelity (Engeström 2011). More generally, relational ethics raises critical questions to any participatory research paradigm that works with a more relational notion of the researcher-researched and aims at ameliorating living conditions from within and for practice. Bang and Vossoughi (2016), for instance, proposed working with the following questions in order to unpack what this ethical stance entails for participatory design research: "What forms of life are our partnerships and designs reinforcing, powering, validating, and transforming? How do particular places, histories, and moments in time shape what is right or wrong and for whom?" (Bang and Vossoughi, 2016, p. 181). Are these deeply moral questions not also relevant to more relational conceptualizations of psychology and psychological knowledge in general?

\section{Kickstarting the Debate: a Few Prototypical Propositions}

The special section that this article introduces seeks to breathe new life into debates that deem these deeply moral questions to be relevant for the production of psychological knowledge, irrespective of the field from which this knowledge is produced. Related contributions engage in theoretical and empirical discussions of research ethics and the moral dimension of psychology, as their interest departs from the everyday practice lived together by researchers and researched. They thus aim to develop theoretical concepts, as well as prototype guidelines and methods, that are relevant for the everyday life practice of the people the research is conducted with. Their research practice calls for the development of a relational research ethics which cannot be separated from ethical considerations that more globally deal with how everyday life can be lived together in good (or "virtuous") ways, as an alternative to the usual utilitarian guidelines and codes that "despite some good intentions, are oblique in addressing some of the most important moral issues in psychology" (Teo 2015, p. 86). These ethical considerations are related to fundamental ontological, epistemological and methodological debates, which discuss psychology's immanent relationality and subjectivity's situatedness in everyday practice. Can, on such grounds, psychology avoid considering itself a moral science (Brinkmann 2011; Tolman 2003)? Does it need to work on intervention and/or emancipation to be or become moral (Tolman 2008; Teo 2009)? And can it do so without becoming instrumental?

In their contribution, O'Doherty and Burgess (2019) illustrate the concrete relevance of posing these grand questions in their discussion of the theoretical foundations implied in current conceptions of informed consent and research participation. Their critique of how current consent practices are unreflectively shaped by ideals of persons as rational and autonomous decision-making agents calls for a more theoretically valid notion of consent. This would need to take into account that decisions about research participation 
are always also situative, and that granting consent always affects a wider circle of people than those explicitly asked. O'Doherty and Burgess therefore suggest to widen the range of relations that researchers consider to be involved and affected when persons are asked to grant consent. Furthermore, they stress that within relational ethics, there is the need for heightened critical vigilance regarding who the research participants are in fact trusting and to what extent. Marginalized and racialized populations (and perhaps everyone else, too) have good reasons for doubting whether researchers truly have their well-being at heart, and current ideals of informed choice do not adequately address these doubts. Relational ethics, with its expanded notion of consent, can offer one possible prototype for productively addressing such shortcomings.

Rajala, Hilppö, Rainio, and Lipponen (forthcoming) explore what postcolonial theorizing implies for research ethics in the context of globalizing education. From this perspective, they discuss and critically scrutinize two prominent approaches for researching and promoting empathy and compassion in education. The authors also outline a novel approach for researching compassion in education that is responsive to postcolonial critique. This approach is based on a transformative onto-epistemology (Stetsenko, 2016), which brings about new ethical demands for researchers who seek not only to examine what is but also what is possible.

Within relational ethics, the consideration of who and in what ways our research efforts impact does not stop with just the research participants and their relations to the researcher and others. What both Søndergaard (2019) and Chimirri (forthcoming) argue for, is that any research effort that adopts a relational ethical standpoint needs to consider not only of human actors. This ethical standpoint also needs to include the significance of and impact on other-than-human life, thus extending across the existential and analytical apparatuses that human actors are unavoidably enmeshed in. Søndergaard highlights the fact that when entering such apparatuses through our research efforts, researchers ought actively to create spaces that allow for all parties to intra-act, or in her words, co-think-feel with the whole of the apparatus. Such a multi-visioned and multi-compassionate perspective would not only address possible selectiveness (i.e., studying only a part of the apparatus) or asymmetry (i.e., caring only for a part of the apparatus), but also function as a possible means for transforming the apparatus itself from within. Chimirri (forthcoming) contribution seeks to epistemologically and ontologically ground Søndergaard's and other posthumanistically inspired perspectives on ethics, and to work out commonalities with dialectical-humanist understandings of research ethics. In his words, when engaging in research as a teleogenetic collaboration, there is a need to acknowledge the determinate in-determinacy of the collaborative effort, as well as the fundamental symmetry between all participants regarding their diverse perspectives on the world. In other words, Chimirri points to how none of the participants nor the researchers have a privileged perspective on the phenomenon under study, and that the joint research effort should be treated as openended, i.e., as having the possibility to lead to different ends than what might have been initially imagined.

In a similar and yet very differently argued and deeply humanistically grounded vein, Freeman (2019) discussion of Martin Buber's and Emmanuel Levinas' work, on the notion of responsibility from a relational ethical perspective, delves more deeply into the experiential relation between the researcher and the researched. Enveloped in a personal and yet generally relevant narrative about the relationship between Freeman 
and his mother after she was diagnosed with dementia, Freeman compels us to think about responsibility as fundamentally primordial, as pre-existing the relationship we have with the people whose lives we want to understand. Highlighting how Levinas' notion of "the face of the other" holds us hostage, Freeman offers a reflective space for us to see and question to what extent our research efforts build on an instrumental positioning of the people we study. Given his own example, Freeman proposes letting the persons we study guide and direct the course of the investigation and in the data generated during the course of this shapeshifting relationship. Importantly, Freeman notes that this stance of being-led-by, rather than leading, others is a valuable ethical ideal, but an ideal paradoxically at odds with the common notions of what it means to do research.

The tension between who the research is fundamentally done for, for the immediate others concretely involved in the research, or for the broader community in the immediate or in the more distant future, for humanity altogether, or also for other-than-human others, are foundational questions that all of this special section's contributions address but cannot unambiguously resolve. This underlines the fact that the utilitarian search for a universalist ethical cookbook for the study of psychologically relevant phenomena such as subjectivity may be in vain, and that more process-oriented, immanently relational and situated alternatives must be developed for any field dealing with psychologically relevant phenomena and questions.

\section{Concluding Remarks}

While the initial contributions to this special section all share the commitment of theorizing research ethics and ethical decision-making as dependent on the concrete everyday circumstances of the researcher and the researched, and on how these play into the situated context of their relational encounter and connectedness, it also becomes evident how the conceptual minutiae of relational ethics deeply depend on the ontological, epistemological and methodological premises engrained in the respective theoretical tradition and perspective. To what extent, for instance, non-human beings (are to) conceptually play into the researcherresearched relationship, or to what extent human beings are considered as interdependent individual beings, or instead as intradependently related collective becomings, and what this implies for knowledge creation, plays fundamentally into how situated relational ethics can be conceived of and put into psychological research practice. As these foundational conceptual questions cannot (and arguably should never) be resolved in an unambiguous way, given the complex and ever-developing character of everyday life and subjectivity, this introduction wishes to conclude by inviting readers to contribute to this special section with further perspectives and knowledge from psychology and other fields dealing with psychologically relevant phenomena and questions, i.e., to join the discussion initiated by this special section in order to further diversify our understandings of what it means to conduct ethically sound and socially just research together with others. This research would seek to serve a common good and avoid instrumentalizing all those others that our research and existence fundamentally depend on, now and in the future.

Acknowledgements Open access funding provided by University of Helsinki including Helsinki University Central Hospital. 
Funding The contribution of Hilppö and Rajala to this article has been funded by the Academy of Finland (Project no: 299191).

Open Access This article is distributed under the terms of the Creative Commons Attribution 4.0 International License (http://creativecommons.org/licenses/by/4.0/), which permits unrestricted use, distribution, and reproduction in any medium, provided you give appropriate credit to the original author(s) and the source, provide a link to the Creative Commons license, and indicate if changes were made.

\section{References}

Allen, G., \& Israel, M. (2018). Moving beyond regulatory compliance: building institutional support for ethical reflection in research. In R. Iphofen \& M. Tolich (Eds.), The SAGE handbook of qualitative research ethics (pp. 453-462). London: Sage.

Andreotti, V. (2011). Actionable postcolonial theory in education. New York: Palgrave McMillan.

Austin, W. (2007). Relational ethics. In L. M. Given (Ed.), The SAGE encyclopedia of qualitative research methods (pp. 748-749). London: Sage.

Bakhtin, M. M. (1993). Toward a philosophy of the act (1st ed.). Austin: University of Texas Press.

Bang, M., \& Vossoughi, S. (2016). Participatory design research and educational justice: studying learning and relations within social change making. Cognition \& Instruction, 34(3), 173-193.

Barad, K. (2007). Meeting the universe halfway: quantum physics and the entanglement of matter and meaning. Durham: Duke University Press.

Baumrind, D. (1964). Some thoughts on ethics of research: after reading Milgram's "behavioral study of obedience". American Psychologist, 19(6), 42.

Brinkmann, S. (2011). Psychology as a moral science: perspectives on normativity. New York: Springer Science + Business Media.

Brinkmann, S. (2012). Qualitative inquiry in everyday life. London: Sage.

Brinkmann, S., \& Kvale, S. (2005). Confronting the ethics of qualitative research. Journal of Constructivist Psychology, 18(2), 157-181.

Brinkmann, S., \& Kvale, S. (2008). Ethics in qualitative psychological research. In C. Willig \& W. StaintonRogers (Eds.), The SAGE handbook of qualitative research in psychology (pp. 263-279). London: Sage.

Campbell, R., \& Morris, M. (2017). The stories we tell: introduction to the special issue on ethical challenges in community psychology research and practice. American Journal of Community Psychology, 60(3-4), $299-301$.

Chimirri, N. (2019). Bridging the post/humanist binary in psychological research with children: toward a more than human ethics for everyday life co- explorations (Forthcoming).

Dewey, J. (1920). Reconstruction in philosophy. Boston: The Beacon Press.

Dingwall, R. (2012). How did we ever get into this mess? The rise of ethical regulation in the social sciences. In K. Love (Ed.), Ethics in social research (pp. 3-26). Emerald Group Publishing Limited.

Ellis, C. (2007). Telling secrets, revealing lives: Relational ethics in research with intimate others. Qualitative Inquiry, 13(1), 3-29.

Emmerich, N. (2016). Reframing research ethics: towards a professional ethics for the social sciences. Sociological Research Online, 21(4), 1-14.

Engeström, Y. (2011). From design experiments to formative interventions. Theory \& Psychology, 21(5), 598-628.

Erickson, F. (2006). Studying side by side: collaborative action ethnography in educational research. In G. Spindler \& L. Hammond (Eds.), Innovations in educational ethnography: theory, methods and results (pp. 235-257). Mahwah: Lawrence Erlbaum.

Etzel, E. F., \& Watson, J. C., II. (2006). Introduction to the special issue: ethics in sport and exercise psychology. Ethics \& Behavior, 16(1), 1-3.

Freeman, M. (2019) Heeding the face of the other: a case study in relational ethics. https://doi.org/10.1007 /s42087-019-00078-6.

Haraway, D. (1991). Simians, cyborgs, and women: the reinvention of nature. London: Free Association Books.

Harlow, L. L., \& Oswald, F. L. (2016). Big data in psychology: introduction to the special issue. Psychological Methods, 21(4), 447.

Hofmeyr, B. (2009). Radical passivity: rethinking ethical agency in Levinas. Dordrecht: Springer.

Holzkamp, K. (2013). Psychology: social self-understanding on the reasons for action in the conduct of everyday life. In E. Schraube \& U. Osterkamp (Eds.), Psychology from the standpoint of the subject. Selected writings of Klaus Holzkamp (pp. 233-341). Basingstoke: Palgrave Macmillan.

Ingold, T. (2013). Making: anthropology, archaeology, art and architecture. Milton Park: Routledge.

Jonsen, A. R., \& Toulmin, S. E. (1988). The abuse of casuistry: a history of moral reasoning. Berkeley: University of California Press. 
Keehn, J. D. (Ed.). (1982). The ethics of psychological research. Oxford: Pergamon Press Ltd.

Lee, N. (1999). The challenge of childhood: distributions of childhood's ambiguity in adult institutions. Childhood, 6(4), 455-474.

Maffesoli, M. (1989). The sociology of everyday life (epistemological elements). Current Sociology, 37(1), 1-16.

Markham, A. N., Tiidenberg, K., \& Herman, A. (2018). Ethics as methods: doing ethics in the era of big data research - introduction. Social Media + Society. https://doi.org/10.1177/2056305118784502.

Martin, J., Sugarman, J., \& Cane, J. (2003). Psychology and the question of agency. New York: State University of New York Press.

Miller, T., Birch, M., Mauthner, M., \& Jessop, J. (2012). Ethics in qualitative research (2nd ed.). London: Sage.

Mol, A. (2008). I eat an apple: on theorizing subjectivities. Subjectivity, 22, 28-37.

O’Doherty K. \& Burgess, M. (2019). Developing psychologically compelling understanding of the involvement of humans in research. https://doi.org/10.1007/s42087-019-00066-w.

Piper, H., \& Simons, H. (2011). Ethical issues in generating public knowledge. In B. Somekh \& C. Lewin (Eds.), Theory and methods in social research (2nd ed., pp. 25-32). London: Sage.

Pollard, C. (2015). What is the right thing to do: use of a relational ethic framework to guide clinical decisionmaking. International Journal of Caring Science, 8(2), 362-368.

Rajala, A., Hilppö, J., Rainio, A., \& Lipponen, L. (2019). Exploring the ethical foundations of research of empathy and compassion in globalizing education (Forthcoming).

Roth, W.-M. (2005). Ethics as social practice: introducing the debate on qualitative Research and ethics. FQS Volume, 6(1), Art. 9.

Roth, W.-M. (2010). Language, learning, context: talking the talk. New York: Routledge.

Shotter, J. (2005). Acknowledging unique others: Ethics, "expressive realism," and social constructionism. Journal of Constructivist Psychology, 18, 103-130.

Shotter, J. (2013). From inter-subjectivity, via inter-objectivity, to intra-objectivity: from a determinate world of separate things to an indeterminate world of inseparable flowing processes. In G. Sammut, P. Daanen, \& F. M. Moghaddam (Eds.), Understanding the self and others: explorations in intersubjectivity and interobjectivity (pp. 31-50). Milton Park: Routledge.

Sleeboom-Faulkner, M., Simpson, B., Burgos-Martinez, E., \& McMurray, J. (2017). The formalization of socialscience research ethics: how did we get there? HAU: Journal of Ethnographic Theory, 7(1), 71-79.

Søndergaard, D. (2019). Psychology, ethics and new materialist thinking - using a study of sexualized digital practices as an example. https://doi.org/10.1007/s42087-019-00064-y.

Stetsenko, A. (2008). From relational ontology to transformative activist stance on development and learning: expanding Vygotsky's (CHAT) project. Cultural Studies of Science Education, 3, 471-491.

Stetsenko, A. (2015). Theory for and as social practice of realizing the future: implications from a transformative activist stance. In J. Martin, J. Sugarman \& K. L. Slaney (Eds.), The Wiley handbook of theoretical and philosophical psychology: methods, approaches, and new directions for social sciences. Wiley.

Stetsenko, A. (2016). The transformative mind: Expanding Vygotsky's approach to development and education. Cambridge, UK: Cambridge University Press.

Strong, T. (2005). Constructivist ethics? Let us talk about them: an introduction to the special issue on ethics and constructivist psychology. Journal of Constructivist Psychology, 18(2), 89-102.

Taylor, T. (1991). The ethics of authenticity. Cambridge, Mass. London: Harvard University Press.

Teo, T. (2009). Philosophical concerns in critical psychology. In D. Fox, I. Prilleltensky, \& S. Austin (Eds.), Critical psychology: an introduction (pp. 36-53). London: Sage.

Teo, T. (2015). Are psychological "ethics codes" morally oblique? Journal of Theoretical and Philosophical Psychology, 35(2), 78-89.

Tolman, C. W. (2003). The moral dimension of psychological practice, theory, and subject matter. In D. Hill \& M. Kral (Eds.), About psychology: essays at the crossroads of history, theory, and philosophy (pp. 35-54). New York: State University of New York Press.

Tolman, C. W. (2008). German critical psychology as emancipatory psychology. In C. I. Cohen \& S. Timimi (Eds.), Liberatory psychiatry: philosophy, politics and mental health (pp. 89-104). Cambridge: Cambridge University Press.

Toulmin, S. E., \& Toulmin, S. (1992). Cosmopolis: the hidden agenda of modernity. Chicago: University of Chicago Press.

Unger, v., Dilger, \& Schönhuth. (2016). Ethikbegutachtung in der sozial- und kulturwissenschaftlichen Forschung? Ein Debattenbeitrag aus soziologischer und ethnologischer Sicht. FQS, 17(3), Art. 20.

Valsiner, J., Marsico, G., Chaudhary, N., Sato, T., \& Dazzani, V. (2016). Psychology as the science of human being. The Yokohama Manifesto. New York: Springer.

Wilson, A., \& Hodgson, P. (2012). Trust, coercion and care: researching marginalized groups. In K. Love (Ed.) Ethics in social research (pp. 111-128). UK: Emerald Group Publishing Limited. 
Publisher's Note Springer Nature remains neutral with regard to jurisdictional claims in published maps and institutional affiliations.

\section{Affiliations}

Jaakko Hilppö ${ }^{1} \cdot$ Niklas Alexander Chimirri $^{2} \cdot$ Antti Rajala $^{1}$

1 University of Helsinki, Siltavuorenpenger 5A, 00010 Helsinki, Finland

2 Roskilde University, Universitetsvej 1, 03.1-NE, DK-4000 Roskilde, Denmark 